\title{
EFEKTIVITAS SELF-HEALING TECHNIQUE SEBAGAI STRATEGI PENURUNAN STRES PADA PENDERITA AUTOIMMUNE DISEASE
}

\author{
Rosyida $^{1}$, Chairun Nisa ${ }^{2}$, Nadhila Azzahra ${ }^{3,}$ Raihanatu Binqalbi Ruzain ${ }^{4}$ \\ 1,2,3,4 Program Studi Ilmu Psikologi, Fakultas Psikologi Universitas Islam Riau, Pekanbaru, Indonesia \\ e-mail: raihanatu.binqolbi@psy.uir.ac.id
}

\begin{abstract}
Autoimmunity is a chronic disease that attacks healthy body tissues; there are more than 80 types of disease. Patients will experience physical function and psychological disorders such as stress. Psychological stress has been implicated in the development and severity of autoimmune diseases with a value of 50\%. This study focused on treatment, including stress management and behavioral interventions to prevent stress-related immune imbalances. This study aims to determine the effectiveness of the self-healing technique in expressing writing and self-talk in reducing the stress level of autoimmune sufferers and in determining the level of social support received. The study was conducted 6-27 July 2021, week 1 expressing writing, week two self-talk, week three social support. The methods used a quantitative type of quasi-experimental design, matching pretestposttest group design. The subjects were 30 patients, 15 patients in the control group and 15 patients in the experimental group. Data analysis used the paired-sample t-test and Wilcoxon test. The results showed that the experimental group experienced a decrease in stress levels than the control group (p-value $=0.001<=$ 0.05). Social support affects patient stress. The conclusion is that giving expressing writing and self-talk therapy can reduce stress levels in autoimmune patients.
\end{abstract}

Keywords: Autoimmune Disease And Stress, Self-Healing Technique, Expressing Writing, Self-Talk

\begin{abstract}
ABSTRAK
Autoimun merupakan penyakit kronis yang menyerang jaringan tubuh sehat, terdapat lebih dari 80 jenis penyakit. Penderita akan mengalami fungsi fisik dan gangguan psikologis seperti stres. Stres psikologis telah terlibat dalam perkembangan dan keparahan penyakit autoimun dengan nilai $50 \%$. Penelitian ini difokuskan pengobatan mencakup manajemen stres dan intervensi perilaku untuk mencegah ketidakseimbangan kekebalan terkait stres. Penelitian ini bertujuan untuk mengetahui efektivitas pemberian terapi self-healing technique berupa expressing writing dan self-talk mampu menurunkan tingkat stres penderita autoimun dan mengetahui tingkat dukungan sosial yang didapat. Penelitian dilakukan 6-27 Juli 2021, minggu 1 expressing writing, minggu 2 self-talk, minggu 3 social support Metode penelitian menggunakan jenis kuantitatif desain quasi eksperimen matching pretest dan posttest group design. Subjek 30 penderita autoimun dari berbagai jenis, 15 penderita kelompok kontrol dan 15 penderita kelompok eksperimen. Analisis data menggunakan paired sample t test dan uji wilcoxon. Hasil penelitian menunjukkan kelompok eksperimen mengalami penurunan tingkat stres daripada kelompok kontrol (nilai $\mathrm{p}=0,001<\mathrm{a}=0,05$ ). Dukungan sosial berpengaruh pada stres penderita. Dapat disimpulkan bahwa pemberian terapi expressing writing dan self-talk dapat menurunkan tingkat stres pada penderita autoimun.
\end{abstract}

Kata Kunci: Autoimun Dan Stres, Self-Healing Technique, Expressing Writing, Self-Talk

\begin{tabular}{|c|c|c|c|}
\hline FIRST RECEIVED: & REVISED: & ACCEPTED: & PUBLISHED: \\
21 August 2021 & 25 October 2021 & 25 October 2021 & 31 October 2021 \\
\hline
\end{tabular}




\section{PENDAHULUAN}

Autoimun merupakan penyakit yang terjadi ketika sistem kekebalan tubuh menyerang jaringan tubuh yang sehat. Ketika sel, jaringan atau organ tubuh manusia justru dianggap sebagai benda asing sehingga dirusak oleh antibody atau imunitas sendiri. Penyakit autoimun bukan disebabkan imunitas yang melemah melainkankan kelainan antibodi yakni adanya peningkatan dan terlalu aktif tidak terkendali sehingga terjadi kerusakan tubuh akibat kekebalan yang terbentuk. Penyakit autoimun dapat menyerang bagian tubuh manapun dengan tanda klasik autoimun berupa inflamasi seperti nyeri, pembengkakan, dan kemerahan. (Purwaningsih, 2013).

Autoimun memiliki 80 jenis penyakit diantaranya Rheumatoid Arthritis (RA), (WHO) 2016 mengungkap penderita sebanyak sebanyak 335 juta penduduk di dunia. Lupus Sistemik Eritematosus (SLE), berdasarkan data WHO penderita Lupus mencapai 5 juta orang, setiap tahunnya bertambah 100 ribu penderita baru. Data info datin 2017 mengungkap, rumah sakit penderita lupus terus bertambah setiap tahunnya. Pada tahun 2014-2016 di Indonesia 1.169 kasus dan jumlah kematian akibat penyakit ini juga meningkat drastis mencapai 550 jiwa. Vitiligo atau dikenal dengan belang putih yang bisa tersebar luas ke seluruh tubuh yang mengandung melanosit, misalnya: rambut dan mata hingga kulit (Taïeb, 2007). Penyakit ini ditemukan pada 0,1-2,9\% populasi dunia (Howitz, 1997). Myasthenia Gravis dengan kelemahan otot yang berfluktuasi memburuk dengan aktivitas dan membaik dengan istirahat sehingga penderita MG sulit untuk melakukan aktivitas sehari-hari dan membuat tekanan psikis yang semakin berat (Conti-Fine et al., 2006). Autoimun berbeda dengan penyakit kronis lainnya seperti kanker, AID, maupun Jantung, penyakit ini merupakan penyakit yang kurang mendapat perhatian. Padahal data menunjukkan autoimun menyerang sekitar $8 \%$ dari 7,8 milyar populasi manusia di seluruh dunia (624 juta jiwa), 78\% diantaranya adalah wanita (Fairweather et al., 2008). Sedangkan Indonesia berdasarkan Kementerian Kesehatan RI, 2017 mencapai 0,5\% atau sekitar 1.250.000 jiwa pada tahun 2017. Hal ini menjadikan autoimun masalah kesehatan yang utama.

Faktor penyebab penyakit autoimun yaitu faktor genetik, lingkungan (seperti stres, makanan, antibiotik, ultraviolet, dan penggunaan obat-obatan) serta hormonal (esterogen). Penderita autoimun juga memiliki kerentanan bagi fungsi tubuh lainnya seperti ginjal, jantung, osteoporosis, otak, sistem pencernaan dikarenakan autoimun merupakan penyakit sistem evolutif (Lahita, 2004). Selain variabel masalah fisik, autoimun juga akan mempengaruhi kesehatan mental bagi penderia autoimun seperti stres, depresi, kecemasan. Hal ini karena penderita harus menghadapi keterbatasan fisik yang menghambat aktivitas sehari-hari dan bisa menjadi stresor khusus untuk orang dengan autoimun (Dewi dkk, 2016). Hale, Radvanski, dan Hassett (2015) mengemukakan bahwa perubahan fisik yang dialami (pertambahan atau penurunan berat badan, moonface, munculnya jerawat, rambut rontok, dan adanya rambut halus pada wajah) mengakibatkan stres pada penderita penyakit 
lupus, dan dapat memengaruhi flare up atau kambuhnya penyakit.

\section{Stres Autoimun}

Ada dua kondisi stresor yang akan dialami oleh penderita autoimun, stresor fisik yang dialami rentan terhadap kelelahan, mudah stres, tidak dapat terkena lebih banyak sinar matahari, dan kondisi fisik yang naik dan turun, penurunan dan penambahan berat badan yang drastis. Pada stresor psikologis penderita akan mengalami proses diagnosis yang panjang, fakta yang harus diterima, sehingga muncul perasaan khawatir akan masa depan, tidak mampu mengendalikan hidup (Plantinga et al., 2017). Kondisi psikis yang buruk akan mempercepat aktivitas penyakit karena dipengaruhi oleh fungsi sistem imun, endokrin, dan sistem saraf pusat. Keadaan ini akan meningkatkan reaksi inflamasi sehingga intensitas nyeri semakin tinggi menyebabkan ketegangan atau stres yang berlangsung terus menerus dan berkepanjangan dapat membahayakan kondisi penderita. Hingga menyebabkan kekambuhan sampai memperburuk kondisi penyakit (Triana, 2015).

Studi mengungkapkan mengenai kondisi psikis yang dialami penderita autoimun yakni sebesar 50\% memiliki tekanan psikologis karena keterlibatan langsung oleh sistem saraf pusat, komplikasi sistemik yang rumit, efek pengobatan, atau penyesuaian yang terkait dengan penyakit kronis (Giffords, 2003). Penelitian yang dilakukan menggunakan Wawancara Diagnostik Internasional Komposit dan Kuesioner Aktivitas Lupus Sistemik menganalisis 326 wanita penderita lupus dan menemukan bahwa $65 \%$ dari pasien ini mengalami suasana hati atau kecemasan seumur hidup. Gangguan lain seperti gangguan depresi mayor (MDD) ditemukan $47 \%$, fobia spesifik ditemukan $24 \%$, gangguan panik $16 \%$, gangguan obsesif-kompulsif $9 \%$, dan gangguan bipolar I 6\% (Bachen et al., 2009).

Pengobatan autoimun saat ini sudah dikembangkan namun sampai sekarang belum mampu ditemukan obat penyembuhannya (Dewi, 2013). Tidak banyak dokter yang mampu mendeteksi penyakit autoimun dan menjadi salah satu faktor pendorong sulit didiagnosanya auotimun. Pada penderita yang mengalami depresi lebih tidak patuh pada aturan pengobatan dan akan membuat kondisi tubuh semakin buruk (Thomas, 2014). Meski sudah ada obat yang berkembang namun harga yang sulit dijangkau penderita. Seharusnya pengobatan penyakit autoimun harus mencakup manajemen stres dan intervensi perilaku untuk mencegah ketidakseimbangan kekebalan terkait stres (Persson et al., 1999). Terlebih bagi mereka yang tidak memiliki lingkungan yang mampu memberikan dukungan secara emosional atau dukungan sosial. Stres merupakan ketidakmampuan mengatasi ancaman yang dihadapi oleh mental, fisik, emosional, dan spiritual manusia serta mempengaruhi keadaan fisik manusia (Priyoto, 2014).

Penelitian yang dilakukan Andi Hadratul Ainiyu, dkk (2020) menggunakan expressing writing pada dua wanita penderita lupus mampu menurunkan stres. Beberapa penelitian menemukan bahwa CBT mampu mengurangi perceived stres penyandang SLE (Goodman dan Gilman 2007), serta terdapat perubahan yang signifikan pada perception of stres dan tingkat kerentanan terhadap stres pada pasien di therapy group dibandingkan pasien-pasien di control group yang tidak menerima treatment CBT (Martin et al., 2010). Jika diperhatikan lebih dekat, penelitian sebelumnya hanya berfokus pada terapi kognitif (CBT), yakni terapi yang berfokus pada penerapan perilaku dan kognitif pada 
proses berpikir. Studi yang dilakukan peneliti Amerika terdapat 40\% memiliki efek samping berupa meninjau kembali apa yang terjadi di masa lalu, pengalaman buruk dan tidak menyenangkan (Utami dan Vessy, 2018). Kelemahan lainnya penderita tidak jujur dengan apa yang mereka tulis, serta tidak semua mampu menulis dengan baik dan runtut.

Penelitian ini lebih menawarkan pendekatan yang lebih menyeluruh pada aspek kognitif, afektif, behaviour (perilaku) dan sosioemosi. Upaya untuk mengatasi stres pada penderita dengan menerapkan self-healing technique yang merupakan metode penyembuhan penyakit bukan dengan obat, melainkan dengan menyembuhkan dan mengeluarkan perasaan dan emosi yang terpendam di dalam tubuh yang dapat dilakukan secara mandiri serta berulang. Penelitian yang dilakukan oleh Ishaq (2007) menunjukkan bahwa $67 \%$ pasien yang mengalami kecemasan berhasil mereduksi tingkat kecemasan dengan self-healing menggunakan energi reiki. Self-healing technique diterapkan dengan kombinasi CBT dan REBT (Rational Emotive Behavior Therapy). CBT yang digunakan berupa expressing writing merupakan terapi perefleksian pikiran dan perasaan terdalam terhadap peristiwa yang tidak menyenangkan yang dilanjutkan dengan REBT berupa self-talk teknik perubahan irasional menjadi pemikiran yang rasional dan juga mengubah emosi negatif dari expressing writing menjadi emosi yang positif. Dalam studi yang membandingkan REBT, Cognitive Therapy (Beck), dan Farmakoterapi, ditemukan hasil bahwa meskipun Cognitive Therapy dan REBT sama-sama efisien dalam menangani klien yang mengalami depresi, namun dalam perhitungan follow-up setelah 6 bulan ternyata REBT memiliki hasil yang lebih signifikan dibandingkan dengan Cognitive Therapy dalam menangani klien yang mengalami depresi (David et al., 2008). Hal tersebut menunjukkan bahwa REBT merupakan treatment yang efektif untuk menangani kondisi depresi sehingga penggabungan keduanya menjadi lebih efesien untuk hasil yang optimal dalam menurunkan stres. Penelitian ini bertujuan untuk mengetahui efektivitas pemberian terapi selfhealing technique berupa expressing writing dan self-talk mampu menurunkan tingkat stres penderita autoimun dan untuk mengetahui social support menjadi fackor tingkat stres pada penderita autoimun. Berdasarkan penjelasan di atas hipotesis penelitian ini adalah ada perbedaan penurunan tingkat stres pada penderita autoimmune disease sebelum serta sesudah diberikannya pelatihan selfhealing technique berupa (expressing writing, self-talk), dan scale social support.

\section{METODE PENELITIAN}

Penelitian dilakukan pada penderita autoimun, belum menikah ataupun sudah menikah yang tersebar di seluruh Indonesia serta bersedia mengikuti sesi pelatihan. Pengambilan sampel dengan teknik probability sampling yaitu purposive sampling atau teknik pengambilan sampel dengan petimbangan tertentu dan dilakukan pada komunitas gravis dan komunitas ketafasfosi autoimun Indonesia.

Penelitian dilakukan secara online sesuai dengan prosedur standar penelitian mengingat saat ini sedang mengalami pandemi dimana peserta akan direkrut secara online melalui media sosial. Mereka akan diminta untuk mengirim email kepada peneliti jika mereka tertarik untuk berpartisipasi. Mereka kemudian akan diminta untuk membaca dan mempertimbangkan seluruh proses penelitian 
dan, jika masih tertarik, untuk menandatangani formulir persetujuan (Informed Consent) dan memperhatikan kerahasiaan (confidentiality) dan kembali ke peneliti melalui email.Jumlah subjek yang ikut serta sebagai peserta penelitian sebanyak 30 orang dengan jenis penyakit yang dimiliki rheumatoid arthritis, lupus eritematosus sistemik, skleroderma, tiroiditis, dan multiple sclerosis, vitiligo, sindrom grave. Wawancara dilakukan dengan menggunakan bantuan kuesioner melalui google form untuk memperoleh data mengenai informasi pribadi seperti jenis kelamin, jenis penyakit autoimun yang diderita serta lama waktu terserang autoimun yang diidap.
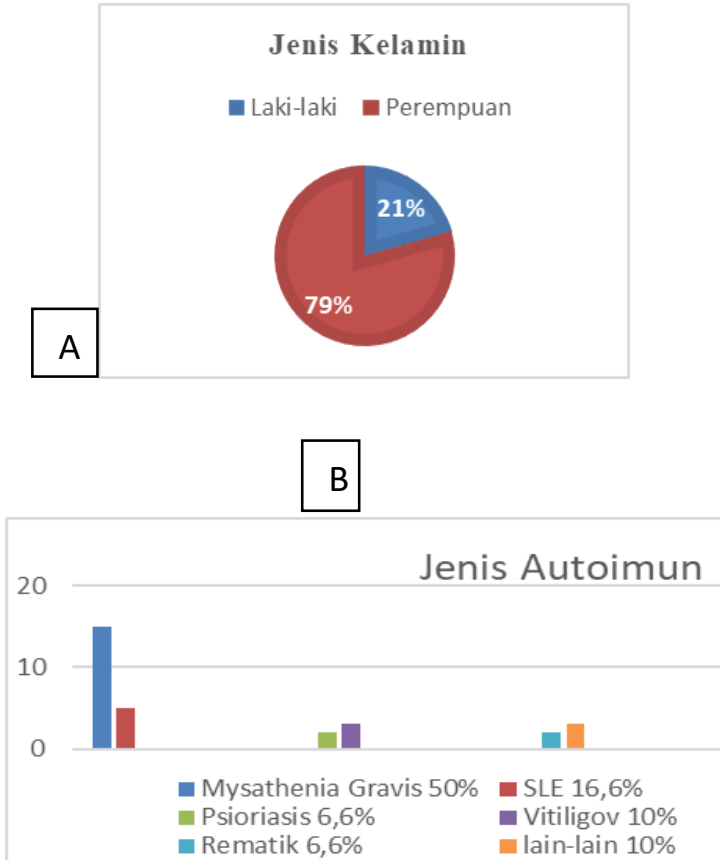

Gambar 1. (a) pengelompokan sampel jenis kelamin,

(b) jenis autoimun.

Gambar 1 (a) menunjukkan jumlah jenis kelamin pada penelitian dengan jumlah wanita merupakan peserta yang lebih dominan dibanding pria, yaitu sebanyak $79 \%$ dari total keseluruhan yakni 24 orang dan jumlah lakilaki sebanyak 6 orang atau 21\%. Gambar 1 (b) menunjukkan penderita dengan jenis Mysathenia Gravis merupakan penyakit autoimun yang paling banyak diderita sebanyak 15 orang, hal ini dikarenakan pengambilam sampel yang dilakukan pada komunitas gravis sehingga menghasilkan data terbanyak. Terdapat penderita yang mengalami lupus atau SLE sebanyak 5 orang, penderita dengan psioriasis dan rematik masing-masing berjumlah 2 orang, vitiligo sebanyak 3 orang, serta berbagai jenis penyakit lainnya yang dikategorikan jenis autoimun paling jarang ditemui sebanyak 3 orang. Pengambilan sampel pada data rentang usia juga dilakukan, sesuai pada gambar 2 (a) rentang usia, (b) lamanya waktu mengidap.

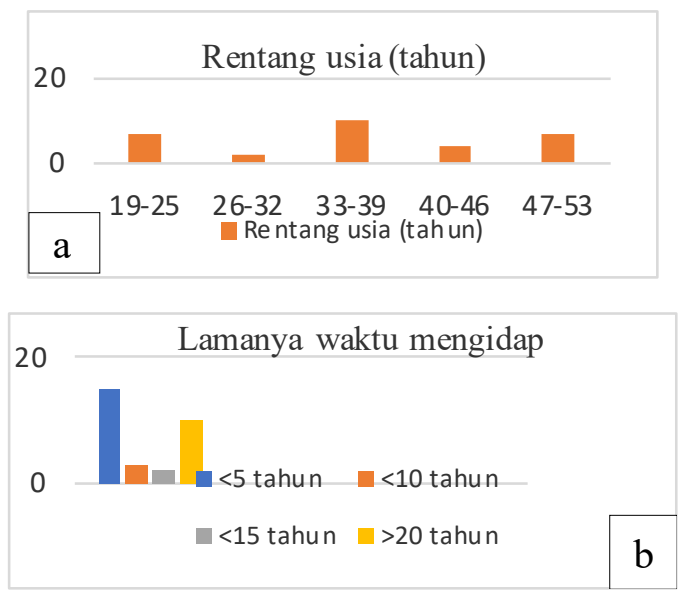

Gambar 2. (a) rentang usia, (b) lamanya waktu mengidap

Dari gambar 2 (a) data rentang usia dari subjek penderita auotimun, sebanyak 10 penderita yang memiliki rentang usia 33-39 tahun dan merupakan usia yang paling dominan, ada sebanyak 7 penderita dari rentang 19-25 tahun, 2 penderita memiliki rentang usia 26-32 tahun, sebanyak 4 penderita dari usia 40-46 tahun dan berasal dari usia 4753 tahun dengan jumlah 7 orang. Peneliti juga memperoleh data lamanya penyakit yang diderita dari para penderita autoimun, berdasarkan gambar diagram di bawah. Lamanya penyakit diderita pada gambar 2 (b) didapatkan data terkait lamanya waktu dari penyakit yang diidap oleh subjek. Sebanyak 15 
orang sudah menderita autoimun kurang lebih 5 tahun, 3 orang selama kurang lebih 10 tahun, 2 orang lainnya $<15$ tahun, dan sebanyak 10 orang yang menderita selama lebih dari 20 tahun.

Penelitian ini menggunakan desain quasi eksperimen matching pretest dan posttest group design dengan membagi kelompok sebanyak 15 orang kelompok eksperimen dan 15 lainnya sebagai kelompok kontrol. Diberikan pelaksanaan pretest secara menyeluruh kemudian mendapat perlakukan yang berbeda antara KE dan KC. Desain penelitian ini digunakan karena adanya keterbatasan subjek penelitian yang jumlah subjek sedikit atau ukuran sampel kecil.

$\begin{array}{llll}\mathrm{KE} & \mathrm{Q}_{1} & \mathrm{X}_{1} & \mathrm{X}_{2} \\ \mathrm{KC} & \mathrm{Q}_{3} & \mathrm{X}_{3} & \end{array}$

Gambar 1. Desain Matching Pretest-Posttest Control Group Design

Gambar di atas merupakan desain eksperimen penelitian dimana pada desain pertama, $\mathrm{KE}$ dan $\mathrm{KC}$ diberikan pretest $\left(\mathrm{Q}_{1}, \mathrm{Q}_{2}\right)$ secara bersamaan dan diberikan perlakuan $\left(\mathrm{X}_{1}\right.$, $\mathrm{X}_{3}$ ) berupa expressing writing dengan bentuk perlakuan yang berbeda kemudian, dan diberikan perlakuan berupa self-talk $\left(\mathrm{X}_{3}\right)$ pada $\mathrm{KE}, \mathrm{KC}$ tidak diberi perlakuan (). Setelahnya kedua kelompok diberi posttest $\left(\mathrm{Q}_{2}, \mathrm{Q}_{4}\right)$.

Penelitian dimulai pada tanggal 6 Juli 2021 selama satu bulan. Prosedur pada penelitian ini sesuai dengan prosedur dari Pannebaker (2010). Pada hari pertama subjek baik kelompok kontrol maupun eksperimen diminta untuk mengisi skala pretest untuk mengetahui tingkat stres pada subjek yang dirasakan pada saat itu setelah melakukan sesi perkenalan terlebih dahulu melalui group yang sudah disiapkan. Pada hari ke dua sampai ke lima di minggu pertama, kedua kelompok subjek diminta untuk menulis selama 20 menit, dengan pembagian kelompok eksperimen menulis pengalaman paling traumatis dan kelompok kontrol menulis aktivitas sehari-hari di atas kertas maupun elektronik.

\section{Instruksi: kelompok eksperimen}

"Selama 4 hari ke depan, kami ingin Anda menuliskan apa yang ada dalam pikiran dan perasaan terdalam Anda tentang pengalaman paling traumatis, menjengkelkan, menyedihkan sepanjang hidup atau masalah emosional yang sangat penting yang telah memengaruhi Anda dan hidup Anda misal cinta, keluarga, kehilangan atau kegagalan. Tulislah di pada buku diary Anda. Dalam tulisan Anda, saya ingin Anda benar-benar melepaskan dan mengeksplorasi emosi dan pikiran terdalam Anda. Anda bisa mengaitkan topik cerita Anda dengan hubungan Anda dan orang lain, termasuk orang tua, kekasih, teman atau kerabat; ke masa lalu Anda, masa kini atau masa depan Anda; atau siapa Anda sebelumnya, siapa Anda ingin menjadi atau siapa Anda sekarang. Anda dapat menulis tentang masalah atau pengalaman umum yang sama pada semua hari penulisan atau tentang topik yang berbeda setiap hari. Semua tulisan Anda akan sepenuhnya dirahasiakan. Jangan khawatir tentang ejaan, tata bahasa, atau struktur kalimat. Satu-satunya aturan adalah begitu Anda mulai menulis, Anda terus menulis sampai waktunya habis".

\section{Instruksi: kelompok kontrol}

"Selama 4 hari ke depan, saya ingin Anda menulis tentang bagaimana Anda menggunakan waktu Anda. Dalam tulisan Anda, kami ingin Anda seobjektif mungkin, dengan berkonsentrasi pada fakta dan detail tentang cara Anda menghabiskan waktu. Kami tidak tertarik pada emosi atau pendapat Anda, melainkan kami ingin Anda mencoba untuk benar-benar objektif. Jangan ragu untuk menulis sedetail mungkin.

Dalam tulisan hari ini, tugas Anda adalah menggambarkan apa yang Anda lakukan kemarin sejak bangun tidur hingga tidur. Misalnya, Anda mungkin mulai ketika alarm berbunyi dan Anda bangun dari tempat tidur. Anda bisa menuliskan

Rosyida, Chairun Nisa, Nadhila Azzahra' Raihanatu Binqalbi Ruzain Efektivitas Self-Healing Technique Sebagai Strategi Penurunan Stres Pada Penderita Autoimmune Disease 
makanan apa yang sudah Anda makan, ke mana Anda pergi, bangunan atau objek apa yang Anda lewati. Tugas menulis pada hari 2-4 instruksi diubah sebagai berikut: tugas pada sesi ke 2 difokuskan pada apa yang Anda telah dilakukan hari ini sejak Anda bangun tidur. Pada sesi ke 3 Anda diminta menuliskan apa yang akan Anda akan lakukan segera setelah sesi menulis ini selesai sampai Anda pergi tidur malam ini dan tugas pada sesi 4 anda diminta menuliskan apa yang akan Anda lakukan minggu depan. Tulislah sampai waktu yang disediakan benar-benar habis"

Sesi 2 dilakukan pada minggu ke dua di hari ke 1-5 yaitu self-talk dimulai 13 Juli 2021 dengan rentang durasi 5-30 menit/ hari, diberikan pada kelompok eksperimen mengubah negative self-talk menjadi positive self-talk. Pemberian skala social support dan posttest pada kedua kelompok dilakukan sejak tanggal 20 Juli 2021 melalui google form. Langkah-langkah yang ditempuh dalam penelitian ini sesuai dengan bagan berikut:

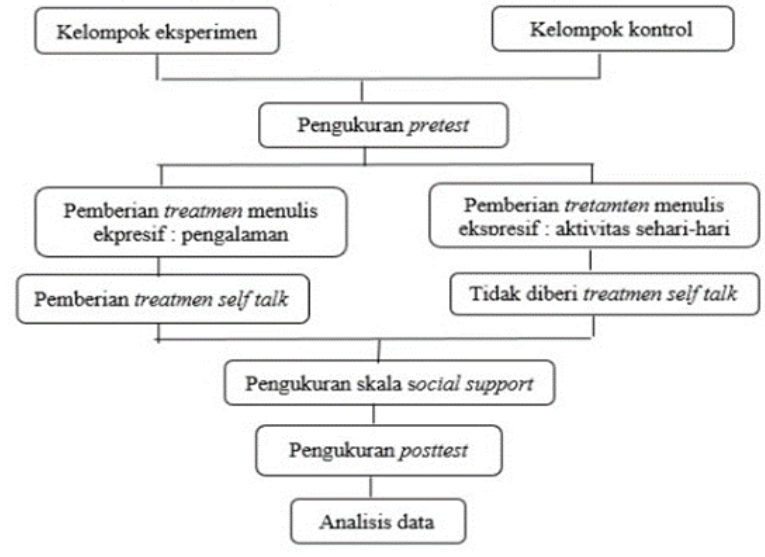

\section{Teknik Pengumpulan Data}

Adapun teknik pengumpulan data yang digunakan dalam penelitian ini adalah kuesioner, proses penelitian dimulai dengan skrining menggunakan Depresi Kecemasan Stres Skala (DASS) stres subtest untuk menentukan tingkat stres sebelum berpartisipasi dalam proses terapi. DASS merupakan skala stres yang diadaptasi oleh Lovibond dan Lovibond (1995) yang

diterjemahkan oleh Damanik (2011). DASS mengukur tingkat stres berdasarkan pada lima aspek stres yang disusun dalam 14 item dimana setiap item memiliki skor mulai dari 0 sampai 4. Skala DASS telah terbukti memiliki tinggi validitas dan reliabilitas untuk mengukur stres, dengan nilai 0,87 dan 0,88 . Hal ini menunjukkan bahwa stres pengukuran menggunakan skala DASS akan diperoleh hasil yang valid dan dapat diandalkan. Jenis skala yang digunakan dalam penelitian ini adalah skala likert, yaitu skala yang digunakan untuk mengukur sikap, pendapat dan persepsi seseorang atau sekelompok orang tentang fenomena sosial. Skala likert dalam penelitian ini digunakan untuk mengukur tingkat stres penderita. Adapun jawaban alternatif dalam skala ini ada 4 yaitu 1: tidak pernah, 2: kadang-kadang, 3: sering, 4: selalu.

\section{Analisis Data}

Pengumpulan data dipisah antara sebelum/sesudah treatment. Data tersebut kemudian akan ditransfer ke SPSS untuk dianalisis. Data akan dianonimkan dengan menambahkan nama kode. File yang berisi data pribadi atau yang dapat diidentifikasi akan dienkripsi atau dilindungi kata sandi. Analisis akan dilakukan atas dasar niat-untukmengobati, dan uji signifikansi akan dilakukan dua sisi pada tingkat 5\%. Tidak ada penyesuaian untuk beberapa pengujian yang akan dilakukan untuk $p$-nilai, bagaimanapun, ukuran efek untuk setiap ukuran hasil akan disajikan. Teknik analisis data yang digunakan dalam penelitian ini menggunakan statistic non parametrik. Metode yang digunakan adalah pendekatan metode kuantitatif yang dilakukan untuk menguji hipotesis menggunakan analisis non parametrik Mann Whitney dan Wilcoxon Test. Penggunaan uji ini bertujuan untuk mengetahui perbedaan tingkat 
stres pada penderita autoimun baik kelompok kontrol maupun kelompok eksperimen akibat adanya perbedaan hasil perlakuan (prates) dan setelah perlakuan (pasca tes) serta dilakukannya tindak lanjut.

\section{HASIL DAN PEMBAHASAN}

Hasil penelitian yang sudah dilakukan menghasilkan data yang telah disusun berdasarkan tabel,

Tabel 2. Data pretest

Indikator berdasarkan skala DASS

\begin{tabular}{|c|c|c|c|}
\hline \multicolumn{2}{|c|}{ Tingkat Rentang Indikator Stres } & KK & $\mathrm{KE}$ \\
\hline Ringan & $15-18$ & 5 & 0 \\
\hline Sedang & $19-25$ & 1 & 7 \\
\hline Berat & $26-33$ & 7 & 4 \\
\hline Sangat berat & $>34$ & 2 & 4 \\
\hline Total & & 15 & 15 \\
\hline
\end{tabular}

Dari hasil penelitian berdasarkan pengisian skala kuesioner DASS, peserta yang mengalami stres ringan hingga sangat berat terjadi perubahan setelah diberi terapi selama 3 minggu. Pada pengukuran pretest, tidak ada peserta pada kelompok eksperimen yang mengalami stres ringan, 7 orang mengalami stres sedang, 4 orang dengan kondisi stres berat dan 4 lainnya mengalami stres sangat berat hingga tidak menemukan kualitas hidupnya. Sedangkan pada kelompok kontrol terdapat 5 orang mengalami stres ringan, 1 orang dengan kondisi stres sedang, 7 orang mengalami stres berat dan terdapat 2 orang mengalami stres sangat berat.

Tabel 3. Data postest Indikator berdasarkan skala DASS

\begin{tabular}{lccc} 
Tingkat & Rentang Indikator & KK & KE \\
\hline Normal & $0-14$ & 1 & 2 \\
Ringan & $15-18$ & 2 & 1 \\
Sedang & $19-25$ & 5 & 10 \\
Berat & $26-33$ & 3 & 2 \\
Sangat berat & $>34$ & 4 & 0 \\
Total & & $\mathbf{1 5}$ & $\mathbf{1 5}$ \\
\hline
\end{tabular}

Dari hasil pengukuran posttest setelah diberikan terapi berupa menulis ekspresif, selftalk kelompok eksperimen yang berjumlah 15 orang mengalami perubahan kondisi, terdapat 2 orang yang tidak mengalami stres yakni dengan kondisi normal, 1 orang stres ringan, 10 orang mengalami stres sedang 2 mengalami stres berat, dan tidak ada mengalami stres sangat berat. Sedangkan pada kelompok kontrol 1 orang sudah tidak mengalami stres, 2 orang stres ringan, 5 orang stres dengan tingkat sedang dan 3 orang mengalami stres berat, 4 orang lainnya mengalami gejala stres sangat berat.

Dari hasil data penelitian tersebut, maka didapatkan bahwa jumlah subjek yang mengalami perubahan tingkat stres pada kelompok kontrol dan eksperimen sebelum dan sesudah perlakuan, terjadi penurunan stres lebih signifikan pada kelompok eksperimen dibandingkan kelompok kontrol.

Tabel 4 hasil perbandingan mean kelompok kontrol (a) kelompok eksperimen (b)

\begin{tabular}{lllc} 
& Grup & N & Mean Rank \\
\hline \hline KK Pretest Posttest & 1 & 15 & 15.23 \\
& 2 & 15 & 15.77 \\
\hline \hline
\end{tabular}

Dari hasil tabel (a) kelompok kontrol menunjukkan mean rank pretest $<$ posttest, $15.23<15.77$ yang artinya terdapat peningkatan stress sebelum dan setelah diberi terapi.

(b) 


\begin{tabular}{lccc} 
Grup & N & Mean Rank \\
\hline \hline KE Pretest Posttest & 1 & 15 & 20.53 \\
& 2 & 15 & 10.47
\end{tabular}

Dari hasil tabel (b) kelompok eksperimen mengalami perubahan penurunan tingkat stress sebelum dan sesudah diberi terapi yang dibuktikan dengan nilai mean rank pretest $>$ posttest, 20.53 $>10.47$.

Tabel 5. Uji Mann Whitney

(a) Kelompok Kontrol

\begin{tabular}{|c|c|c|}
\hline Test & Z Score & Signifikan \\
\hline Pretest Postest & 0,166 & 0,868 \\
\hline
\end{tabular}

(b) Kelompok Eksperimen

\begin{tabular}{lrc}
\hline \hline Test & Z Score & Signifikan \\
\hline \hline Pretest-Postest & 3,153 & 0,002 \\
\hline \hline
\end{tabular}

Berdasarkan tabel 4.3 dilakukan uji mann whitney didapatkan hasil bahwa ada tidak ada perbedaan yang signifikan pada kelompok kontrol sebelum dan setelah diberi terapi dengan nilai signifikansi 0,868 $(\mathrm{P}>0,05)$. Sedangkan pada kelompok eksperimen terdapat perbedaan yang signifikan sebelum dan setelah diberi terapi yang dibuktikan dengan nilai signifikan 0,002 $(\mathrm{P}<0,005)$.

\section{Tabel 7. Kelompok eksperimen uji Wilcoxon}

\begin{tabular}{llc}
\hline \hline Tes & Skor Z & Nilai Signifikan \\
\hline \hline Pretest-posttest & 3,414 & 0,001 \\
\hline \hline
\end{tabular}

Berdasarkan tabel 6. dilakukan uji wilcoxon, didapatkan hasil bahwa ada perbedaan tingkat stres melalui terapi selfhealing berupa expressing writing dan self-talk daripada sebelum diberikan terapi dengan skor Z 3,414 dan nilai signifikan 0,001 ( $\operatorname{Sig}<0,05)$.

Tabel 8. Kelompok kontrol uji Wilcoxon

\begin{tabular}{lcc}
\hline \hline Tes & Skor $\mathbf{Z}$ & Nilai Signifikan \\
\hline \hline Pretest-posttest & 0,313 & 0,754 \\
\hline \hline
\end{tabular}

Berdasarkan tabel 7 kelompok kontrol metode Wilcoxon antara pra test dan postest nilai $\mathrm{Z}$ adalah 0,313 dengan nilai siginifikansi $0,754$ ( $p>0,05)$. Sehingga menunjukkan tidak ada perbedaan yang signifikan antara tangkat stres pada pretest dan postestDari seluruh data yang sudah didapatkan, maka dihasilkan penelitian bahwa terdapat perbedaan yang signifikan pada tingkat penurunan stres dari penderita autoimun terkhusus pada kelompok eksperimen yang sudah diberi terapi terlebih dahulu selama tiga minggu berupa expressing writing, self-talk dan mengetahui kondisi dukungan sosial penderita melalui pengisian kuesioner skala MSPSS. Penelitian ini bertujuan untuk mengetahui efek terapi selfhealing technique pada tingkat stres penderita autoimun. Tinggi rendahnya penderita autoimun dapat dilihat dari lima aspek yang diperoleh kesulitan menenangkan diri, merasa gelisah, iritabilitas, respon berlebihan, dan ketidaksabaran (Lovibond \& Lovibond,1995).

Berdasarkan hasil analisis yang telah dilakukan, terdapat perbedaan yang signifikan dalam tingkat stres pada penderita autoimun setelah mengikuti keseluruhan terapi $\mathrm{p}=0,001$ $(\mathrm{p}<0,05)$. Berdasarkan hasil wawancara pada salah satu subjek ES yang menderita myasthenia gravis mengaku bahwa gejala awal yang dirasakan menjadi mudah lelah, nyeri pada kerongkongan hingga sulit menelan, bicara mulai cadel, melemahnya otot-otot ketika berjalan, sampai hilangnya nafsu makan. keadaanya menjadi lebih setelah diberikan terapi, hal ini sejalan dengan penelitian yang dilakukan oleh Sosinsky dan Kaufmann (2007) MG memiliki ciri kelelahan dan kelemahan pada otot. Seperti, kelemahan 
otot anggota gerak akibat peningkatan aktivitas. Hale, Radvanski, dan Hasset (2015) mengemukakan bahwa penderita autoimun mengalami perubahan pada fisik dan penurunan kesehatan secara signifikan, hal ini juga dirasakan pada semua subjek setelah bertahun-tahun menderita tanpa mengetahui diagnosa yang dijelas, sampai mengetahuinya kemudian mengakui seolah ingin marah, hidupnya semakin hancur, merasa tidak berdaya, adanya perasaan kecewa tanpa penyebab yang lebih jelas. Sebelum mengetahui diagnosa awal auotimun, subjek menderita sakit tanpa kejelasan selama bertahun-tahun, hal ini dikarenakan dokter sulit mendiagnosis gejala awal autoimun, menurut Waluyo (2010) bahwa gejala dari penyakit autoimun sangat luas akibatnya diagnosis dan pengobatan menjadi sulit.

Subjek mengaku bahwa penyakit autoimun yang diderita dapat menjadi lebih parah dari sebelumnya ketika subjek terlalu memikirkan penyakit yang dialami, menerima hinaan dari lingkungan sekitar, dan belum dapat menerima kenyataan bahwa dirinya menderita autoimun, sehingga subjek memaksakan diri untuk beraktivitas yang seharusnya tidak dilakukan pada penderita autoimun. Hal ini sejalan dengan yang dikemukakan Lupien, et al (2009) bahwa stresor dapat berupa hinaan fisik, trauma, pengerahan tenaga, dan pada saat badan dipaksa bekerja di luar kemampuan.

Setelah diberikan terapi, subjek kelompok eksperimen menjadi lebih terbuka dari sebelum diberi terapi, dapat menceritakan banyak hal yang terjadi padanya. Memberitahu banyak informasi dan merasa lebih tenang, ada tingkat tekanan stres pada subjek setelah minggu pertama melakukan expressing writing meski ada subjek lainnya yang masih merasa bingung akan apa yang harus ditulis.

Hasil ini sejalan dengan penelitian yang dilakukan oleh Rahmawati (2013) bahwa menulis ekspresif efektif dalam mengurangi stres pada individu. Hal ini juga berdasarkan teori dari Qonitatin dkk (2011) bahwa menulis tentang pengalaman traumatis berhubungan erat dengan peningkatan efek psikologis yang positif, dan dalam jangka panjang dapat menurunkan masalah- masalah kesehatan. Menulis dapat meningkatkan kinerja lobus frontalis otak, sehingga saat seseorang menulis dapat membersihkan pikiran- pikirannya dari hal-hal buruk yang ingin kita lakukan akibat stres.

Sesi self-talk diberikan, subjek melakukan self-talk dengan tipe Self-speak, pembicaraan yang diucapkan secara sadar (dengan suara) kepada diri sendiri atau disampaikan kepada orang lain mengenai diri sendiri dan Selfconversation, yakni self-talk yang dilakukan dengan membuat suatu percakapan (dengan atau tanpa suara) kepada diri sendiri. Menurut Schafer (Erford, 2016) mengemukakan teknik self-talk dapat mengubah keyakinan irasional dan mengembangkan pikiran menjadi lebih sehat ke arah yang lebih positif. Menurut (Jim, 2011) Self-talk positif merupakan adanya pernyataan positif yang dapat mendorong seseorang dan membantu dalam mengatasi kesulitan yang mereka hadapi karena memberikan efek positif berupa emosi-emosi positif dengan mengungkap kata misalnya, "saya bisa, kuat". Hal ini terbukti mampu memberikan energi positif bagi penderita kelompok eksperimen dengan responsif yang ditampilkan pada sesi penutup menjadi lebih enerjik dari pada sesi pembuka pelatihan pemberian terapi. Ini membuktikan bahwa penggabungan expressing writing (CBT) dan self-talk (REBT) menjadi self-healing technique mampu menurunkan tingkat stres dalam waktu yang lebih singkat daripada 
dilakukan secara terpisah dengan membutuhkan waktu lebih lama. Seperti halnya Niles et al (2014) dalam penelitiannya yang diikuti oleh 116 dewasa muda dengan KE: 59 dan KC: 57 bahwa terdapat efek positif dari menulis ekspresif pada kecemasan dewasa muda dengan metode empat sesi menulis 20 menit, 1 hari/sesi, rata-rata 25 hari/ 30 hari sebanyak 4 kali pengulangan.

Sesuai dengan penelitian Santosa dkk (2014) bahwa REBT dan CBT dapat secara efektif menurunkan derajat simptom-simptom depresi yang dialami oleh 4 orang pasien penyakit jantung ini. Hal tersebut terlihat dari perubahan derajat emosi negatif (affective), pikiran negatif (cognitive), serta kondisi fisik dan perilaku (somatic-behavioral) yang terkait dengan simptom depresi tersebut.

Hasil penelitian dalam skala dukungan sosial menunjukkan bahwa beberapa subjek tidak mendapat dukungan sosial secara maksimal. Berdasarkan kuesioner yang disebar terdapat 5 penderita yang sama sekali tidak mendapat dukungan sosial secara utuh, 10 penderita mendapatkan dukungan sosial tidak penuh dan 15 lainnya mendapat dukungan sosial lebih baik. Hal ini mempengaruhi tingkat stres pada penderita. Hal ini sejalan dengan penelitian Nugraha dan Srisayekti (2012) terhadap dua pasien lupus dengan metode one to one selama 2 minggu dengan $2 \mathrm{jam} / \mathrm{sesi}$ mampu memenuhi kebutuhan pasien akan dukungan emosional dengan menghadiri meyakinkan, peran sebagai teman yang mendengarkan pasien. Social support dapat membuat seseorang merasa nyaman, didukung, dicintai pada saat individu tersebut dalam kondisi stres, terbangunya perasaan harga diri, kompeten dan bernilai. Social support dapat diberikan oleh keluarga, kerabat, rekan kerja, dan temanteman di lingkungan sosial.

\section{SIMPULAN}

Pada penelitian ini dapat disimpulkan bahwa kelompok eksperimen terapi expressing writing dan self-talk mampu memberikan penurunan tingkat stres pada penderita autoimun (nilai $\mathrm{p}=0,001<\mathrm{a}=0,05$ ). Sedangkan untuk kelompok kontrol $(p=0,754$ $>a=0,05)$. Pada pengisian skala dukungan sosial dapat disimpulkan mempengaruhi tingkat stres penderita. Hingga expressing writing, self-talk dan social support menjadi efektivitas untuk mengatasi penurunan tingkat stres pada penderita autoimmune disease. Hasil penelitian ini dapat dijadikan referensi sebagai bahan informasi di bidang ilmu promosi kesehatan dengan memberikan edukasi kesehatan khususnya tentang manajemen stres pada penderita penyakit kronis untuk meningkatkan pengetahuan tentang pentingnya kesehatan psikologis. Diharapkan bagi peneliti selanjutnya agar dapat menambah jumlah responden dan memperluas cakupan penelitian sehingga dapat terjangkau sasaran penelitian untuk mengetahui sejauh mana perbedaan efektivitas, serta diharapkan juga dalam pelaksanaan penelitian ini dilakukan dengan metode lain dan untuk pengukuran kemampuan anak bisa menggunakan lembar observasi.

\section{DAFTAR PUSTAKA}

Ainiyu, A. H., Murdiana, S. and Ridfah, A. (2020). Pengaruh Menulis Ekspresif dalam Menurunkan Stres pada Wanita Penderita Penyakit Lupus. Humanitas Jurnal Psikologi, 4(2): 131-148. doi: 10.28932/humanitas.v4i2.2402. https://doi.org/10.1016/j.autrev.2004.09 .002

Bachen, E. A., Chesney, M. A., \& Criswell, L. A. (2009). Prevalence of mood and 
anxiety disorders in women with systemic lupus erythematosus. Arthritis \& Rheumatism, 61(6), 822-829. https://doi.org/10.1002/art.24519

Conti-Fine, B. M., Milani, M., \& Kaminski, H. J. (2006). Myasthenia gravis: Past, present, and future. Journal of Clinical Investigation, 116(11), 2843-2854. https://doi.org/10.1172/jci29894

David, D., Szentagotai, A., Lupu, V., and Cosman, D. (2008). Rational emotive behavior therapy, cognitive therapy, and medication in the treatment of major depressive disorder: A randomized clinical trial, posttreatment outcomes, and six-month followup. Journal of Clinical Psychology. 64: 28-746

Dewi, E, S,. (2013). Efektivitas Terapi Kompres Dingin dalam Menurunkan Stres Orang dengan Lupus (Odapus) Dewasa Muda di Perhimpunan Masyarakat Peduli Lupus Parahita Malang. Skripsi Sarjana. Universitas Brawijaya Malang

Dewi, Kadek dan Yasa. (2016). Pengaruh Good Corporate Governance, Profitabilitas, Likuiditas, dan Solvabilitas terhadap Peringkat Obligasi. E-Jurnal Akuntansi Universitas Udayana, 16(2): 1063-1090.

Erford, B.T. (2016). 40 Teknik yang harus di Ketahui Setiap Konselor, Edisi Kedua. Yogyakarta: Pustaka Pelajar.

Fairweather, D., Frisancho-Kiss, S., \& Rose, N. R. (2008). Sex differences in autoimmune disease from a pathological perspective. The American Journal of Pathology, 173(3), 600-609. https://doi.org/10.2353/ajpath.2008.071 008

Giffords, E. D. (2003). Understanding and managing systemic lupus Erythematosus
(SLE). Social Work in Health Care, 37(4), 57-72. https://doi.org/10.1300/j010v37n04_04 Goodman dan Gilman. (2007). Dasar Farmakologi Terapi. Edisi 10. Buku Kedokteran. ITB: Bandung.

Hale, E. D., Radvanski, D. C., and Hassett, A. L. (2015). The man-in-the-moon face: a qualitative study of body image, selfimage and medication use in systemic lupus erythematosus. Rheumatology, 54(7):1220-1225.

Howitz, J. (1977). Prevalence of vitiligo. Archives of Dermatology, 113(1): 47.

Hatzigeorgiadis, A., Zourbanos, N., Mpoumpaki, S., \& Theodorakis, Y. (2009). Mechanisms underlying the selftalk-performance relationship: The effects of motivational self-talk on selfconfidence and anxiety. Psychology of Sport and Exercise, 10(1), 186-192. https://doi.org/10.1016/j.psychsport.200 8.07.009

Ishaq, I. (2007). Mengenal Usui Reiki I dan II Intensif. Jakarta: Delaprasta Publishing

Jim, R. (2011). Dahsyatnya Terapi Bicara Positive Self-talk Therapy. Yogyakarta: Arta Pustaka.

Lahita, R. G. (2004). Systemic lupus Erythematosus. Elsevier.

Lovibond, P, F dan Lovibond, S, H. (1995). The Struktur Keadaan Emosi Negatif: Perbandingan Depresi Anxiety Stres Scales (DASS) dengan Beck Depresi dan Inventaris Kecemasan. Penelitian Perilaku dan Terapi. 33(3) : 335-43.

Lupien, S. J., McEwen, B. S., Gunnar, M. R., and Heim, C. (2009). Effects of stres throughout the lifespan on the brain, behaviour and cognition. Nature reviews. Neuroscience, 10(6): 434-445. https://doi.org/10.1038/nrn2639 
Martín, A., Varona, S., Navarrete, A., dan Cocero, M.J. (2010). Encapsulation and Co-Precipitation Processes with Supercritical Fluids : Applications with Essential Oils, Spain, J. The Open Chemical Engineering. 4: 31-41.

Niles, A. N., Haltom, K. E., Mulvenna, C. M., Lieberman, M. D., \& Stanton, A. L. (2013). Randomized controlled trial of expressive writing for psychological and physical health: The moderating role of emotional expressivity. Anxiety, Stres, \& Coping, 27(1), 1-17. https://doi.org/10.1080/10615806.2013. 802308

Nugraha, S., \& Srisayekti, W. (2012). Social Support and Stres Symptoms of Lupus Patients. Indonesian Psychological Journal, 28(1), 1-11.

Persson, Kåre Berglund, Dick Sahlbe, L. (1999). undefined. Scandinavian Journal of Rheumatology, 28(3), 137144.

https://doi.org/10.1080/0300974995015 4194

Plantinga, L. et al. (2017). Perceived Stres and Reported Cognitive Symptoms among Georgia Patients with Systemic Lupus Erythematosus. HHS Public Access Lupus, 26(10):1064-1071. doi: 10.1177/0961203317693095.

Priyoto. (2014). Teori Sikap dan Perilaku dalam Kesehatan. Yogyakarta: Nuha Medika.

Purwaningsih, E. (2013). Disfungsi Telomer Pada Penyakit Autoimun Telomere Dysfunction in Autoimmune Diseases. Jurnal Kedokteran Yarsi, 21(1):41-049. Qonitatin, N., Widyawati .S.,\& Asih. G.Y. (2011). Pengaruh Katarsis dalam Menulis Ekspresif sebagai Intervensi
Depresi Ringan pada Mahasiswa. Jurnal Psikologi Undip. 9(1).

Rahmawati, Rahmawati, dkk. (2013). Peningkatan Keterampilan Menulis Narasi Siswa Kelas IV Melalui Model Examples Non-Examples. Joyful Learning Journal. 2(2).

Santosa, A, Urip, P.Asteria, D, K. (2014). Efektivitas Rational Emotive Behavior Therapy Untuk Menurunkan Derajat Simptom Depresi Pada Pasien Jantung. Science and Technology. (1): 1-15.

Sosinsky MS dan Kaufmann P. (2007). Myasthenia Gravis \& Other Disorders of the Neuromuscular Junction. in: Brust JCM (ed.). Neurology: Current Diagnosis and Treatment. USA: Lange Medical Books/McGraw-Hill. Hal. 350356

Taïeb, A., \& Picardo, M. (2007). The definition and assessment of vitiligo: A consensus report of the vitiligo European task force. Pigment Cell Research, 20(1), 27-35. https://doi.org/10.1111/j.16000749.2006.00355.x

Thomas, D. E. (2014). Lupus Encyclopedia: A Comprehensive Guide for Patients and Families. Maryland, MD: Johns Hopkins University Press

Triana, W. (2015). Hubungan Intensitas Nyeri dengan Tingkat Kecemasan Pada Pasien Artritis Reumatoid di Rumah Sakit Daerah Dr. Soebandi Kabupaten Jember.Universitas Jember. (online). URL:

http://repository.unej.ac.id/handle/1234 56789/73146, diakses 11 Desember 2020 . 
Al-Hikmah: Jurnal Agama Dan Ilmu Pengetahuan Vol. 18 No.2, Oktober 2021

Utami, S, H, dan Vessy,D,F.,(2018). Studi : 40 Persen Terapi Kognitif Berikan Efek Samping Buruk. https://www.suara.com/health/2018/1 0/16/181025/studi-40-persen-terapi-
P-ISSN 1412-5382

E-ISSN 2598-2168

kognitif-berikan-efek-samping-

buruk?page $=$ all. Diakses tanggal 26 Agustus 2021.

Waluyo, L. (2010). Teknik dan Metode Dasar dalam Mikrobiologi. UMM Press 